\title{
Regulative and standard requirements on facades in Slovakia and their mutual comparison with selected European countries
}

\author{
Róbert Leško and Martin Lopušniak \\ Technical University of Košice, Faculty of Civil Engineering, Department of Building Physics, \\ Vysokoškolská 4, 04200 Košice, Slovak republic
}

\begin{abstract}
Increasingly stricter requirements on the energy effective and environmentfriendly construction of buildings are projected even to the other parts of project design including fire safety. Resulting requirements for fire safety can mutually differ in spite of stricter requirements in individual European countries. The subject of this paper is represented by description of the solution of façade fire safety in Slovakia with subsequent comparison of requirements on class of reaction to fire and fire resistance of façades between selected European countries on two structures differing by their height. From the viewpoint of class of reaction to fire, the Slovak system appears to be strictest one, on the contrary, from the viewpoint of fire resistance as the least strict one. The necessity of modification of fire safety solution in Slovakia follows from analysis carried out taking into account wider application of products with class of reaction to fire class other than A1, or A2-s1, d0.
\end{abstract}

\section{INTRODUCTION}

The design of façades has been considerably changed during last several years. Nowadays, the façade forms not only means of expression of the structure, but requirements of most areas of design solution are put on it. They are represented mainly by the architectonic-structural design, thermal and acoustic protection, daylight, technological and technical solutions, and last but not least by fire safety. In general, the façade is a sandwich type building structure consisting of the mixture of heterogeneous building products. Just heterogeneity of used building product multiplies demandingness of its final design even due to possible propagation of fire on its outer surface. According to $\mathrm{O}^{\prime}$ Connor [1], the height of flames can achieve the level of more than $5 \mathrm{~m}$ depending on the size of fire load and surfaces opened to fire. If the façade also contains combustible components, in addition to quicker development of fire, it also could exercise an influence on the reduction of resulting value of building structure fire resistance [2]. Therefore it is necessary to find optimum (safe or acceptable) level of the use of building products and building structures within the framework of the façade structure.

Requirement on the uniform solution within the framework of requirements on the façade structure for all European countries appears to be unreal. This follows mainly from different national approaches to the solution of fire safety. This fact has also been confirmed by study [3] of requirements for fire 


\section{MATEC Web of Conferences}

safety of façades within Nordic countries. In spite of the fact that fire risk and traditional nature of the construction are very similar in Nordic countries, resulting requirements are different. Differences in the solution across European countries are manifested not only within the framework of requirements on reaction to fire, but also in requirements on fire resistance [4].

Continual development in the field of material engineering is projected into innovative proposals of design solution. Fire safety, as a profession part of the design solution should be operatively responded to the aforementioned fact. Therefore it is very questionable, whether the existing method of the solution of fire safety in Slovakia (developed almost 40 years ago) is able to reflect really demands of the existing progress of the building industry. Therefore a summary of the solution of fire safety of façades in Slovakia has been created within the framework of this paper with the comparison of requirements in selected European countries in order of creating the basis for possible optimizing of the existing solution of fire safety in Slovakia.

The design of façades of multi-storey buildings in Slovakia is not so variable from the point of view of materials used as it could be possible with the existing progress of building industry. In comparison with the other European countries, building products with different class of reaction to fire than A1 or A2-s1,d0 can be used within the framework of the construction of façades only in very limited degree. Therefore substantiation of this state and its mutual comparison with the solution used in European countries on model cases is the subject of this paper.

\section{SOLUTION OF FIRE SAFETY IN SLOVAKIA}

The solution of fire safety of buildings in Slovakia (former Czechoslovakia) in the form as it is known today was described by REICHEL [5-8] at the turn of the $70 \mathrm{~s}$ and $80 \mathrm{~s}$. Structure of the solution consists of fields that are assessed in the most of countries of Europe and the world. The determination of requirements for building structures is one of these fields. Requirements on fire safety within the framework of assessment of building structures are focused mainly on risk of the origin and propagation of fire, physiological effects of smoke, heat and the like [9]. Taking into account the fact that the building industry has passed through gradual changes since the $70 \mathrm{~s}$, it was necessary to transfer this development even into requirements of fire safety. During almost 40-year solution of fire safety in Slovakia, the method of classification of building structures can be divided from the point of view of fire safety into two development stages.

\subsection{Classification of building structures - elements of structure}

In early stages of the solution of fire safety in Slovakia, no reliable method existed for unambiguous verification of individual building structures [5]. Therefore building structures were evaluated separately according to fire resistance and fire-technical properties (combustibility) of the building materials used. Classification of the structure depending on the type of building materials used was preceded with relative toilsome and lengthy calculation of their overall weight. In spite of criteria set in the aforementioned way, according to REICHEL [5] this method did not represent the most suitable method for assessment of fire safety, therefore it has been optimized.

It has been shown, after years of the designing practice that assessment of individual elements of structure and subsequently assessment of the structure as a whole is more suitable method than to assess the structure from the point of view of its useful properties [6]. On the basis of this method of assessment of building structures that is used up to the present time, impact of combustible building products on fire intensity and bearing capacity of building structure was taken into account. Mutual position of building products in the building structure also plays an important role in this method of assessment. Depending on reaction to fire and position of building products, structures are identified as an element of structure. Elements of structure are divided into three basic types, D1, D2 and D3 (Table 1, Fig. 1) according 
Table 1. Criteria for sorting of elements of structure [5].

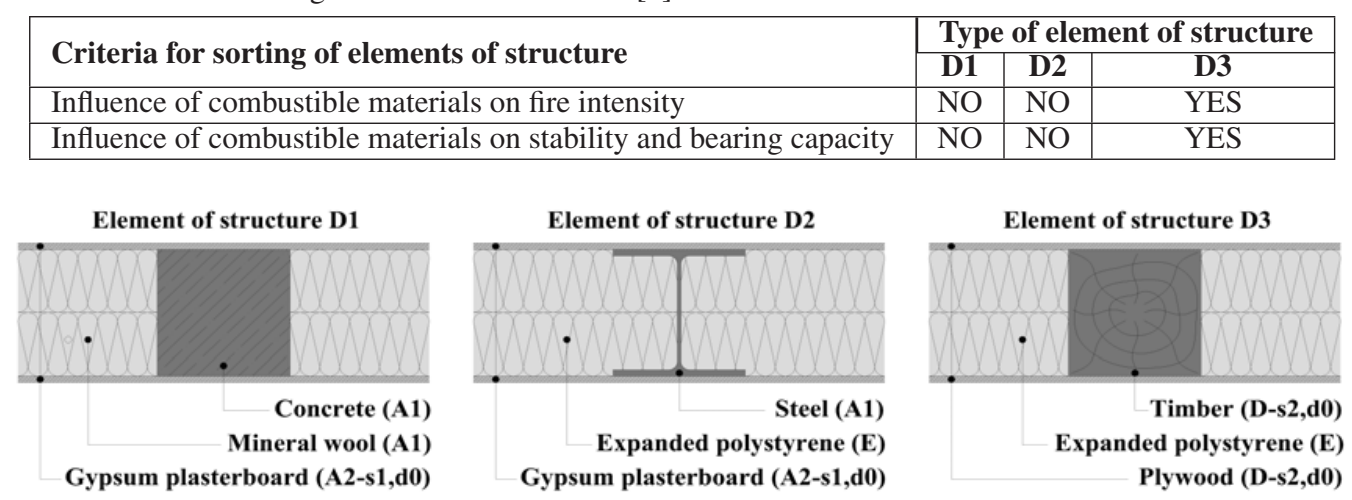

Figure 1. Elements of structure.

to impact of combustible products on intensity of fire, stability and bearing capacity of the building structure.

Element of structure of the D1 type is the building structure that does not increase intensity of fire, because it consists exclusively of building products with class of reaction to fire maximum A2-s1, d0. Element of structure of the D2 type is the building structure that does not increase intensity of fire, because its building products with class of reaction to fire other than A1 or A2-s1, d0 are completely closed between building products with class of resistance to fire of A1 or A2-s1, d0. Bearing function of this element of structure must be provided exclusively by building products with class of reaction to fire of A1 or A2-s1, d0. Element of structure of the D3 type is the building structure that increases intensity of fire and that does not meet aforementioned requirements, while it can be made of building products without any limitation of class of reaction to fire [STNEN] (Fig. 1).

\subsection{Classification of structures - type of construction}

As a set of building structures becomes the construction system from the construction point of view, a set of building structures creates, from the point of view of fire safety, the construction system (type of construction). The nature of type of construction is determined on the basis of type of building structures (elements of structure) used. Like in the case of the classification of building structures, the classification of types of construction is one of main factors for layout of elements of structure (Fig. 2).

From the point of view of fire safety, buildings are divided on the basis of their utilization of purpose (for example buildings intended for housing and accommodation, buildings intended for health services and the like), but requirements on material-construction design of building structures (class of reaction to fire and fire resistance) are determined on the basis of a type of construction of the building (Table 2).

\subsection{Façade as an element of fire safety in Slovakia}

Designing of buildings has been developing in various stages since half of the $70 \mathrm{~s}$, when effort for reduction of heat consumption for heating was asserted. Gradual reduction of thermal losses through thermal exchange structures (including façades) become the primary goal. From this point of view, it was necessary to make requirements on individual coefficients gradually stricter expressing the allowed quantity of heat that is transmitted to exterior through individual building structures. The development of requirements from the point of view of heat transmission coefficient through the façade is stated in Fig. 3 on the left [11]. Figure 3 on the right states the quantity of heat that can be released from the outer 


\section{MATEC Web of Conferences}
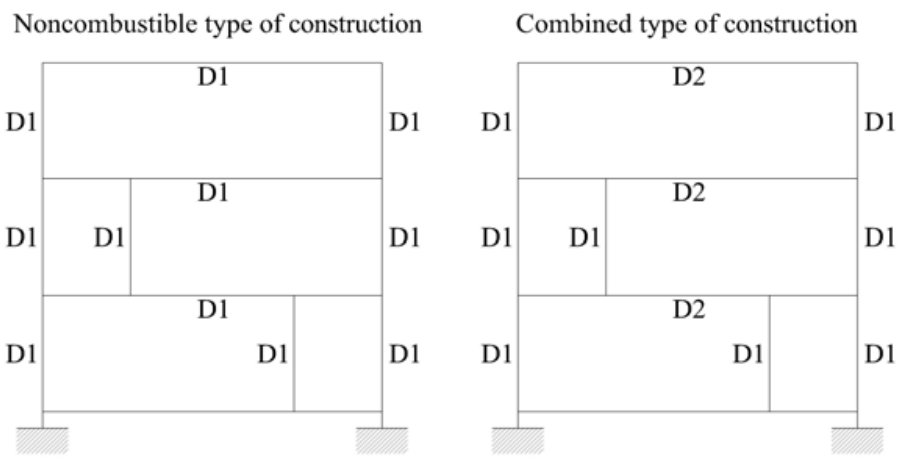

Combustible type of construction

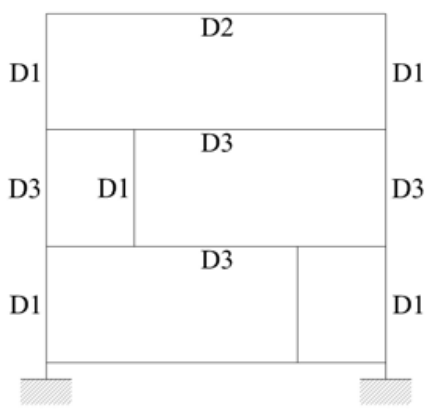

Figure 2. Type of construction.

Table 2. Fire height limit and requirements on fire resistance of building structures [10].

\begin{tabular}{|c|c|c|c|}
\hline \multirow{2}{*}{ Type of building (except family houses) } & \multicolumn{3}{|c|}{ Type of construction } \\
\hline & Noncombustible & Combined & Combustible \\
\hline $\begin{array}{l}\text { Buildings for living and accommodation } \\
\text { (dwelling houses, hotels, guest-houses etc.) }\end{array}$ & $\begin{array}{c}\mathrm{FH}=\text { NO LIMIT } \\
\mathrm{R}(\mathrm{EI}) 30-120\end{array}$ & $\begin{array}{l}\mathrm{NoS}=1-3 \text { storeys } \\
\mathrm{R}(\mathrm{EI}) 30-45\end{array}$ & $\begin{array}{l}\text { NoS }=1-2 \text { storeys } \\
\text { R(EI) } 30-45\end{array}$ \\
\hline $\begin{array}{l}\text { Buildings for medical services } \\
\text { (hospitals, health care, nursery, etc.) }\end{array}$ & $\begin{array}{l}\mathrm{FH}=\text { NO LIMIT } \\
\mathrm{R}(\mathrm{EI}) 30-180\end{array}$ & $\begin{array}{l}\mathrm{NoS}=1-2 \text { storeys } \\
\mathrm{R}(\mathrm{EI}) 30-120\end{array}$ & $\begin{array}{l}\text { NoS }=1-2 \text { storeys } \\
\text { R(EI) } 30-180\end{array}$ \\
\hline $\begin{array}{l}\text { Non-industrial buildings (schools, office } \\
\text { buildings, libraries, services, shops, etc.) }\end{array}$ & $\begin{array}{c}\mathrm{FH}=\text { NO LIMIT } \\
\mathrm{R}(\mathrm{EI}) 30-180\end{array}$ & $\begin{array}{l}\mathrm{FH}=0-22,5 \mathrm{~m} \\
\mathrm{R}(\mathrm{EI}) 30-120\end{array}$ & $\begin{array}{l}\mathrm{FH}=0-9 \mathrm{~m} \\
\mathrm{R}(\mathrm{EI}) 30-120\end{array}$ \\
\hline
\end{tabular}
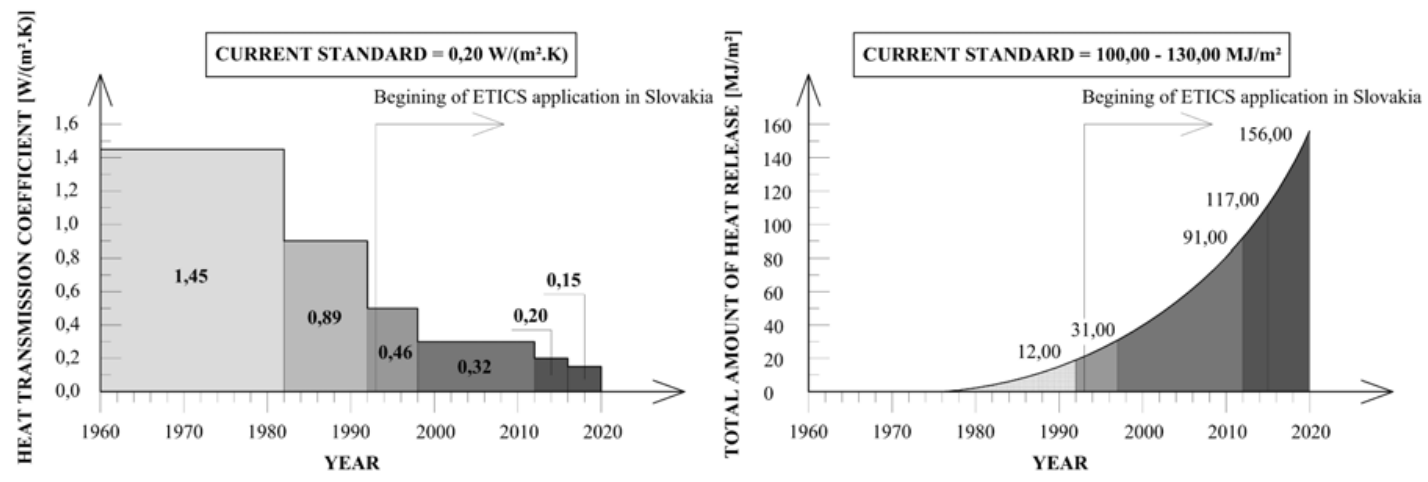

Figure 3. Increase in demands on the heat transmission coefficient value and total amount of heat release from façade [11].

surface of façade during fire corresponding to values of heat transmission coefficient of heat insulation system from thermal insulation material on the basis of foam polystyrene (this is the most frequently used form of the thermal insulation system in Slovakia).

By 1980, the presence of building products with class of reaction to fire other than A1 or A2, s1, d0 within the framework of façade structure was minimal (they were represented, for example, by primary forms of disruption of the heat bridge and the like) causing that the classification of construction elements appeared to be suitable at that time. This state had been gradually changed with the development of building products, mainly on the basis of plastics and composite materials. The fact that this progress has not been caught within the framework of determination of structural elements, 

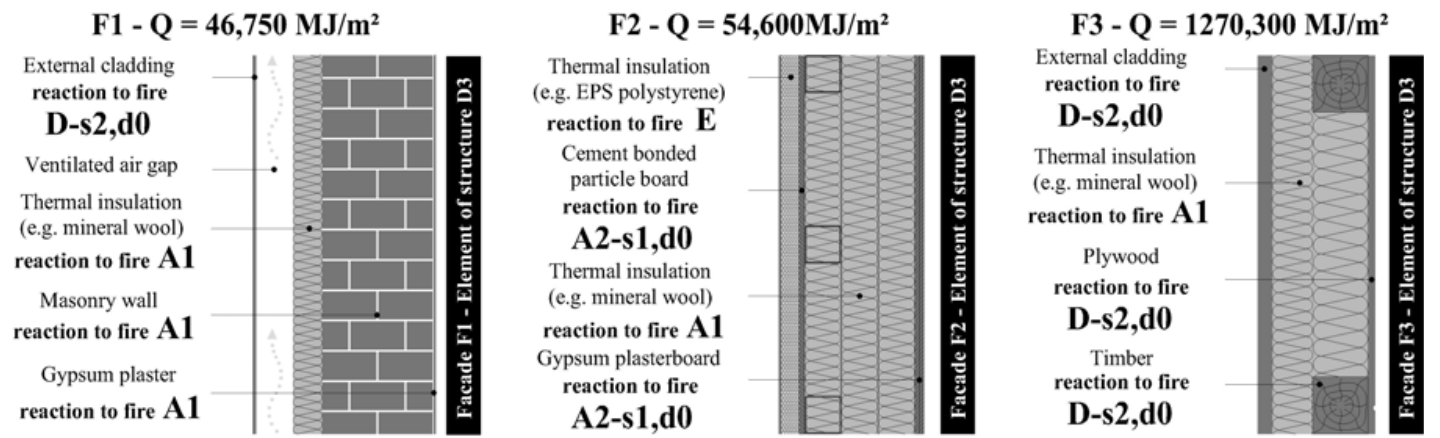

Figure 4. Total amount of heat release from façade in various material composition.

the design of façades of multi-storey buildings can become problematic with increasing demands on energy efficiency from the point of view of fire safety by 2020. The situation, when three apparently different variants of façade are classified as the identical structural element in spite of different material composition, is an example of this state (Fig. 4).

Differences between compared alternatives are visible not only in the material composition, but also in the quantity of heat that can be released from their surface. Alternative F3 is able, in comparison with alternative F2 or F1, to release from its surface almost 30-multiple larger quantity of heat during fire. The use of the existing method of classification of building structures causes that any sandwich building structure (for example façade) consisting of building products with class of reaction to fire other than A1 or A2-s1, d0 is defined as the D2 or D3 element of structure (Fig. 1). Actual quantity of heat released from its material during fire (Fig. 4), or degree of risk that can be represented by it in the case of fire for its vertical development, are not taken into account. This state, taking into account increasing demands on energy effectiveness and permanent sustainability of buildings appears to be unsustainable.

\section{REQUIREMENTS ON FIRE SAFETY IN SELECTED EUROPEAN COUNTRIES}

Each country of Europe and the world solves fire safety of buildings individually. But the basic scheme of the solution of fire safety is not different in most of countries. Assessment of designing building structures is one of parts of this scheme. Taking into account the fact that designing façades from the point of view of fire safety is discussed at the present time not only in Slovakia, but across Europe, the list of requirements of selected European countries was prepared within the framework of this paper on two model cases.

\subsection{Areas of assessment}

Requirements on outer surface of façade and on bearing structure providing its stability (in cases of façade with bearing function) are important from the point of view of the solution of fire safety of façades. Requirements on their designing are changed depending on the height of buildings, or the number of its storeys. Two height variants were taking into account for the purposes of this analysis. The first variant takes into account height level of the floor of the highest storey at $10.0 \mathrm{~m}$, and the second one at $22.0 \mathrm{~m}$. These are heights corresponding to 4 or 8 overhead storeys. The building is intended for residential purposes (housing or housing with polyfunction). Within the framework of aforementioned requirements (Table 3) on the outer surface of façade and bearing structures providing its stability the element preventing the propagation of fire on façade (fire cut-offs, fire barriers and the like) had not been 
Table 3. Fire safety requirements on facades and buildings structures in European countries [3, 4, 10, 12-19].

\begin{tabular}{|c|c|c|c|c|}
\hline \multirow{2}{*}{ European country } & \multicolumn{2}{|c|}{ Fire safety requirements $(\mathrm{h} \leq \mathbf{1 0 , 0} \mathrm{m})$} & \multicolumn{2}{|c|}{ Fire safety requirements $(\mathrm{h} \leq \mathbf{2 2 , 0} \mathrm{m})$} \\
\hline & Facades & Building structures & Facades & Building structures \\
\hline Slovak republic & A2-s1,d0 & A2-s1,d0 - R 45 & A2-s1,d0 & A2-s1,d0 - R 45 \\
\hline Czech republic & $\mathrm{B}-\mathrm{s} 1, \mathrm{~d} 0$ & A2-s1,d0 - R 45 & B-s1,d0* & $\mathrm{A} 2-\mathrm{s} 1, \mathrm{~d} 0-\mathrm{R} 60$ \\
\hline Austria & D-d0 & R 60 & B-d1 & R 90 \\
\hline Germany & $\mathrm{DCM}^{\mathrm{e}}$ & R 60 & $\mathrm{DCM}^{\mathrm{e}}$ & $\mathrm{A} 2-\mathrm{s} 1, \mathrm{~d} 0-\mathrm{R} 90$ \\
\hline Great Britain & No provisions $^{\text {a }}$ & R 60 & B-s3,d2, C-s3,d2 ${ }^{\mathrm{d}}$ & R 90 \\
\hline Finland & $\mathrm{D}-\mathrm{s} 2, \mathrm{~d} 2^{\mathrm{c}}$ & R 60 & B-s1,d0 & $\mathrm{A} 2-\mathrm{s} 1, \mathrm{~d} 0-\mathrm{R} 120$ \\
\hline Norway & $\mathrm{D}-\mathrm{s} 3, \mathrm{~d} 0^{\mathrm{b}}$ & $\mathrm{A} 2-\mathrm{s} 1, \mathrm{~d} 0-\mathrm{R} 60$ & $\mathrm{~B}-\mathrm{s} 3, \mathrm{~d} 0$ & A2-s1,d0 - R 90 \\
\hline Estonia & D-s2,d2 & R $30-$ R 60 & $\mathrm{D}-\mathrm{s} 2, \mathrm{~d} 2$ & A2-s1,d0 R60 - R120 \\
\hline Belgium & D-s3,d1 & R 60 & B-s3,d1 & R 90 \\
\hline
\end{tabular}

Notes:

*Till the $12 \mathrm{~m}$ building fire height acceptable B-s1, d0 with barriers (max. A2-s1, d0), over $12 \mathrm{~m}$ to the top of the building max. A2-s1, d0 (see Fig. 5).

$\mathrm{DCM}^{\mathrm{e}}$ Difficult combustible material - reaction to fire B - C.

${ }^{a}$ No provisions in respect of the boundary indicated.

${ }^{\mathrm{b}}$ Maximum 4 storeys - depending on risk class and hazard class and if the fire risk in the facade is limited and the risk of fire spread to other buildings is low.

${ }^{c}$ Accepted in $2-4$ storey building depending on its building class.

${ }^{d}$ Till the $18 \mathrm{~m}$ building height acceptable C-s3, d2, over $18 \mathrm{~m}$ to the top of the building C-s3, d2 (see Fig. 5).

taken into account. Reference buildings are designed as separately standing ones with sufficient distance separations for the prevention of transfer of fire to adjacent buildings. Fire load of these buildings was taken into account at the level of $60 \mathrm{~kg} / \mathrm{m}^{2}$, or $600 \mathrm{MJ} / \mathrm{m}^{2}$.

Visual comparison of differences in requirements on the outer surface of façade from the point of view of class of reaction to fire and fire resistance of bearing elements providing its stability is stated in Fig. 5 .

\section{RESULTS}

The following facts can be stated on the basis of analysis of requirements on outer surfaces of façades and fire resistance of bearing elements providing its stability:

- Strictest requirements are put in Slovakia from the point of view of class of reaction to fire on the outer surface of façades,

- Slovakia requires, as the only country among compared countries, full-area non-combustible design of facades in both assessed height alternatives of buildings, while this fact will not be influenced by possible equipment of building with active elements of fire protection (for example sprinklers, smoke detection and the like),

- The application of building products with class of reaction to fire other than A1 or A2-s1, d0 is higher in the other assessed countries than in Slovakia, but it depends on particular requirements on fire safety,

- From the point of view of requirements on fire resistance of bearing elements providing stability of the façade, Slovakia is the country with least strict requirements (value of $\mathrm{R} 45$ represents national criterion of fire resistance used in the Czech Republic and in the Slovak Republic).

\section{DISCUSSION}

An approach is applied in Slovakia in the existing solution of fire safety, within which the "optimal state" between requirements of fire safety (both active and passive one) and resulting level of protection against possible fire is found only with difficulties (Fig. 6). 
$2^{\text {nd }}$ International Seminar for Fire Safety of Facades, Lund (Sweden), 2016
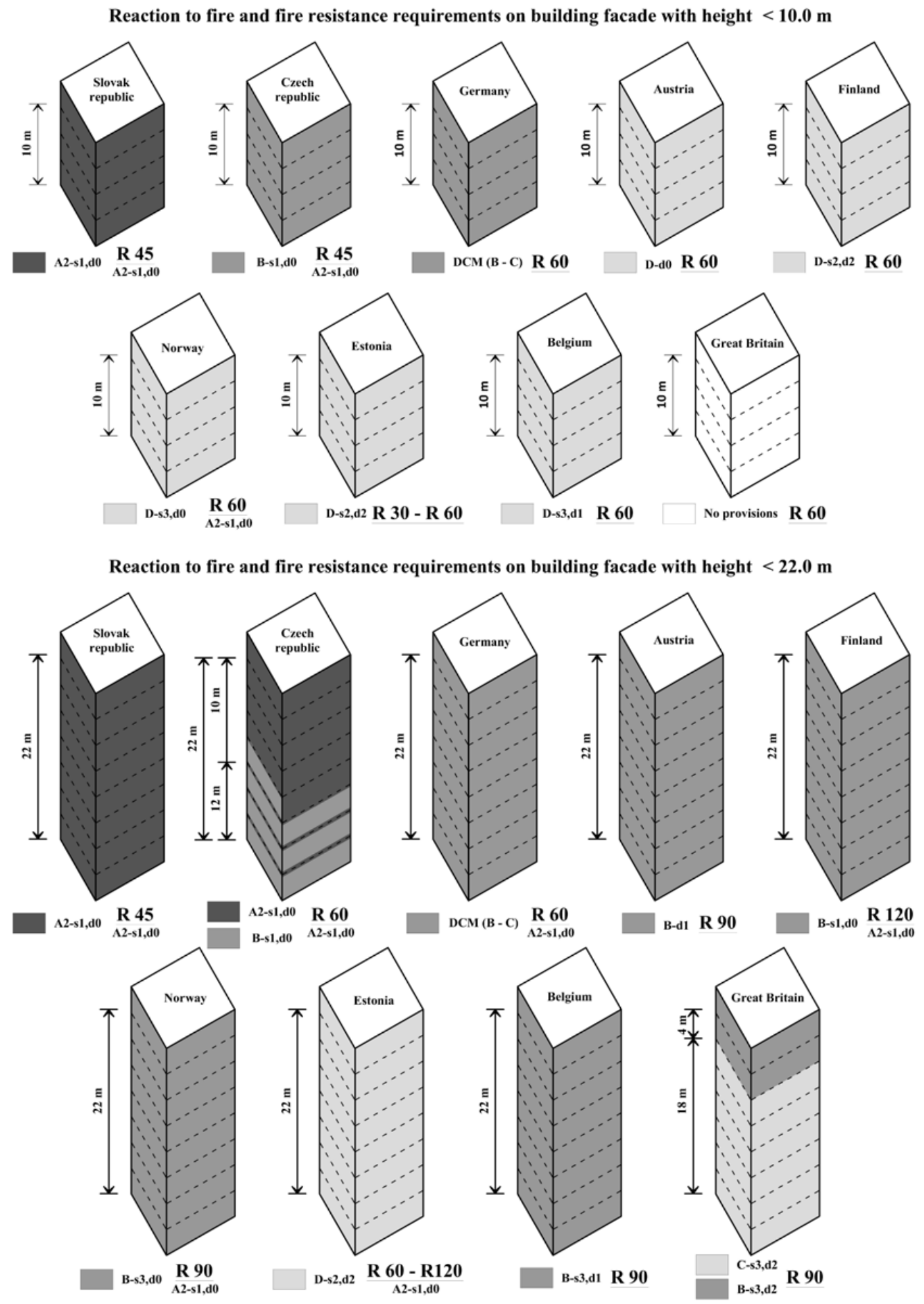

Figure 5. Mutual comparison of façade requirements in selected European countries on buildings with height till 10 and till $22 \mathrm{~m}$. 

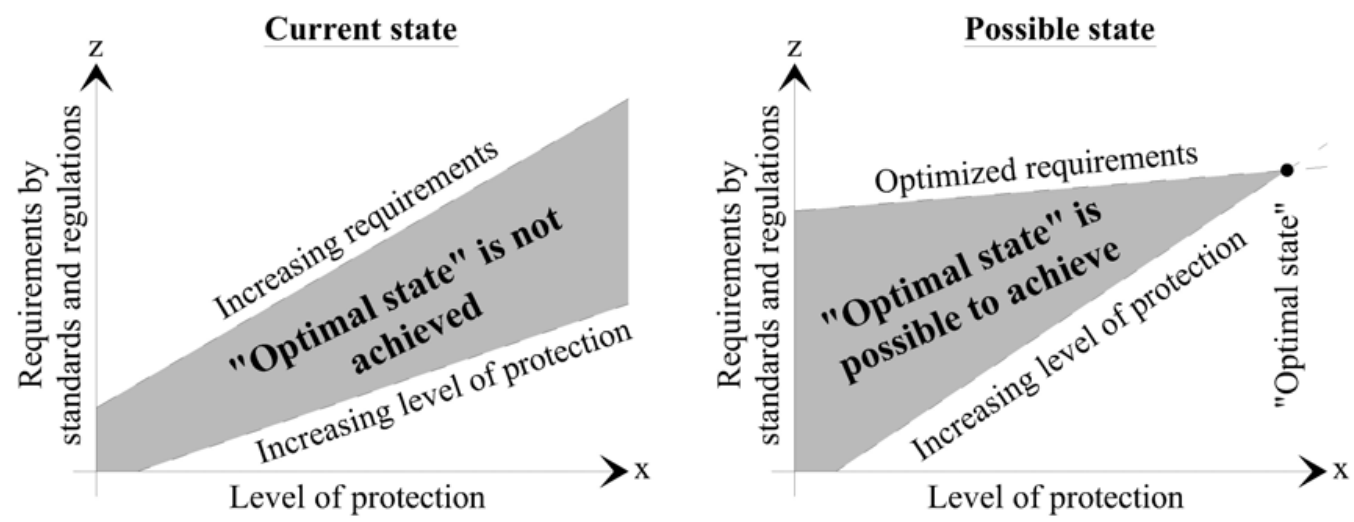

Figure 6. Current and possible state of fire safety in Slovakia.

Carried out analysis pointed out the fact that Slovakia appears as one of European countries, in which one of strictest requirements on fire safety are applied from the point of view of material-construction requirements. The more intensive application of active fire protection systems appears to be the solution of this situation. They are currently applied (mainly due to costs on their implementation) only in buildings, where they are required by the legislation. The reduction of requirements on fire resistance of building structures in Great Britain [16], or the reduction of risk of propagation of fire on the outer surface of façade made of combustible building products in Sweden using sprinklers can be stated as examples.

Not only energy efficiency, but also environment-friendly construction with outlook to 2020 requires modification of the existing concept of solution of fire safety in Slovakia. According to [20], the increase of allowed height to five and more overhead storeys is expected by 2020 in European countries, which limits at the present time the use of buildings with bearing system on the basis of wood up to two overhead storeys (including Slovakia). In [20], it is also stated that increased awareness of designing wooden structures from the point of fire safety, in combination with systems of active fire safety (for example sprinklers, smoke detection and the like) was the reason why some European countries allowed the use of higher wooden structures by modification of their regulations. Similar process, built on the basis verified by system and case studies, should also be implemented in Slovakia for the development of the building industry and dire safety.

\section{CONCLUSION}

The paper deals with different approach to requirements on fire safety of façades. Results have shown that requirements on fire safety of façades are considerably different between Slovakia and the other European countries assessed. Omitting the classification of elements of structure that is not used in any of assessed countries (except the Czech Republic) appears to be one of variants of optimizing the existing solution. On the basis of the aforementioned results, it is necessary to change the existing classification of fire safety of façades in Slovakia in order it would reflect the development and innovations in the building industry.

This paper was created by support of grant project 1/0835/14 "Experimental research of physical fragment properties and construction details of building envelopes in non-stationary hygro-thermal conditions". 
$2^{\text {nd }}$ International Seminar for Fire Safety of Facades, Lund (Sweden), 2016

\section{References}

[1] O Connor, D. J. „Building Facade or Fire Safety Facade?”, Council on Tall Buildings and Urban Habitat Journal. 9, 30-39, 2008.

[2] White, N., Delichatsios, M., "Fire Hazards of Exterior Wall Assemblies Containing Combustible Components", The Fire Protection Research Foundation, Quincy, MA, 2014.

[3] Strömgren, M., Albrektsson, J., Johansson, A., Almgren, E., "Comparative Analysis of Façade Regulations in the Nordic Countries" Proceedings of the International seminar for fire safety of facades, Paris, France, 14-15 November, 2013.

[4] Loebus, S., Friquin, K., Tulamo, T. S., SmartTES - Innovation in timber construction for the modernization of the building envelope, Book 5 - Fire safety, WoodWisdom-Net, 2014.

[5] Reichel, V., Navrhovaní požární bezpečnosti staveb I., Nakladatelství technické literatury ve Středisku interních publikací, Praha, 1978.

[6] Reichel, V., Navrhovaní požární bezpečnosti staveb II., Nakladatelství technické literatury ve Středisku interních publikací, Praha, 1979.

[7] Reichel, V., Navrhovaní požární bezpečnosti staveb III., Nakladatelství technické literatury ve Středisku interních publikací, Praha, 1980.

[8] Reichel, V., Navrhovaní požární bezpečnosti staveb, Nakladatelství technické literatury ve Středisku interních publikací, Praha, 1984.

[9] Ďurica, T., "Horavost' stavebných materiálov - faktor požiarnej bezpečnosti stavieb", Stavebné hmoty, 12-14, 2010.

[10] STN 92 0201-2, Structural fire protection, Common regulations, Part 2: Building constructions, 2007.

[11] Sternová, Z. a kol., Energetická hospodárnost’ a energetická certifikácia budov, JAGA Group, Bratislava, 2010.

[12] ČSN 73 0802, Fire protection of buildings - Non-industrial buildings, 2009.

[13] ČSN 73 0810, Fire protection of buildings - General requirements, 2009.

[14] The National Building Code of Finland - Fire safety of buildings, Regulations and guidelines, 2002.

[15] Yves, M., "Fire regulations, research and challenges for fire safe use of bio-based building products - State of the art of Belgium", Proceedings of the Bio-based Building Products and Fire Safe Design of Buildings - Recent Developments - Book of Abstracts, 3-4, Barcelona, Spain, 20-21 April, 2015.

[16] The Building Regulation, Fire Safety, Approved Document B, Volume 2 - Buildings other than Dwellinghouses, 2010.

[17] Decree no. 315, Fire safety of building and a building part. 2005.

[18] Werther, N., Hofmann, V., Merk, M., Winter, S., "Fire safety regulations in Germany and limitations for the use bio-based building products - State of the art report", Proceedings of the Bio-based Building Products and Fire Safe Design of Buildings - Recent Developments - Book of Abstracts, 15-18, Barcelona, Spain, 20-21 April, 2015.

[19] Österreichisches Institut für Bautechnik OiB-Richtlinie 2, Brandschutz, 2011.

[20] Gerrard, R., Barber, D., Wolski, A., "Fire safety Challenges of Tall Wood Buildings", The Fire Protection Research Foundation, Quincy, USA, 2013. 